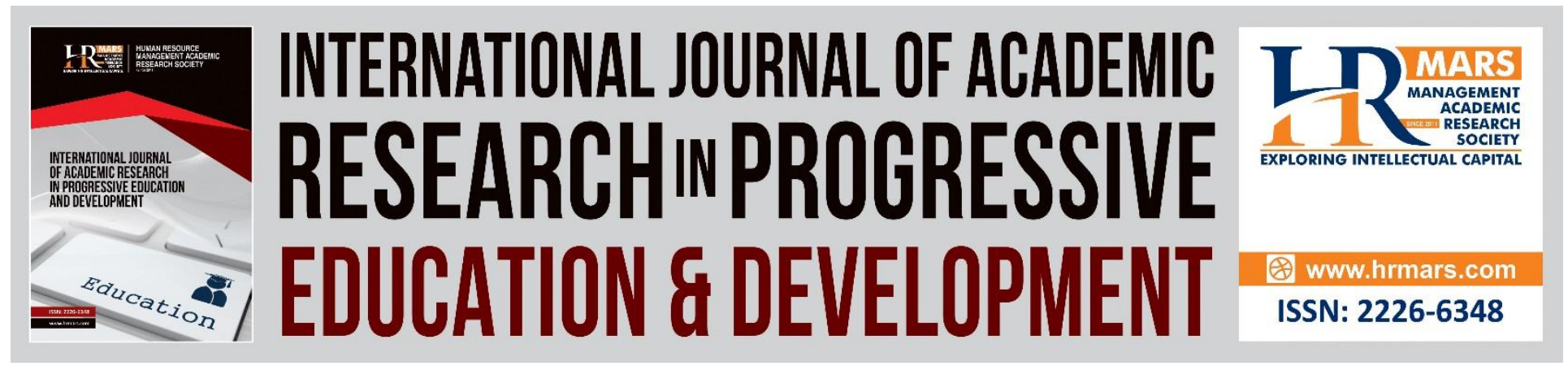

\title{
Inclusion of Children with Visual Impairments in Regular Schools - A Zimbabwean Perspective
}

\section{Francis Emson Dakwa}

To Link this Article: http://dx.doi.org/10.6007/IJARPED/v3-i1/680

DOI: $10.6007 /$ IJARPED/v3-i1/680

Received: 04 January 2014, Revised: 29 January 2014, Accepted: 19 February 2014

Published Online: 07 March 2014

In-Text Citation: (Dakwa, 2014)

To Cite this Article: Dakwa, F. E. (2014). Inclusion of Children with Visual Impairments in Regular Schools - A Zimbabwean Perspective. International Journal of Academic Research in Progressive Education and Development, 3(1), 96-105.

Copyright: (C) 2014 The Author(s)

Published by Human Resource Management Academic Research Society (www.hrmars.com)

This article is published under the Creative Commons Attribution (CC BY 4.0) license. Anyone may reproduce, distribute, translate and create derivative works of this article (for both commercial and non-commercial purposes), subject to full attribution to the original publication and authors. The full terms of this license may be seen at: http://creativecommons.org/licences/by/4.0/legalcode

Vol. 3(1) 2014, Pg. 96 - 105

http://hrmars.com/index.php/pages/detail/IJARPED

JOURNAL HOMEPAGE

Full Terms \& Conditions of access and use can be found at http://hrmars.com/index.php/pages/detail/publication-ethics 


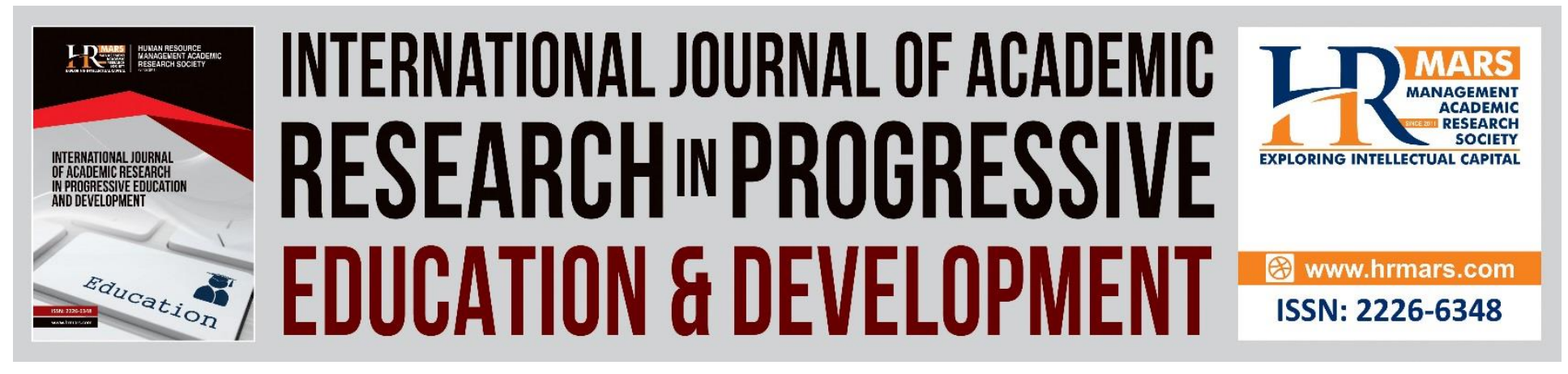

\title{
Inclusion of Children with Visual Impairments in Regular Schools - A Zimbabwean Perspective
}

\author{
Francis Emson Dakwa \\ Great Zimbabwe University
}

\begin{abstract}
The study sought to examine the inclusion of children with visual impairments within regular school settings from a Zimbabwean perspective. The population of the study included teachers and children with visual impairments, as well as blind and children with low vision included in the regular primary and secondary schools. A qualitative survey design was employed in which 30 teachers and 40 pupils were interviewed to solicit their views and observations on the progress made in including children with visual impairments in the mainstream. The study concluded that inclusion was not successful due to lack of material and human resources. Classroom teachers in the regular classes lacked training in handling children with visual impairments. The learning needs of children who were blind and those with low vision were not met, hence, these children failed to participate in sport and other school activities. Assistive devices to support inclusion of both blind children and those with low vision were inadequate. Items that broke down could not be repaired owing to lack of repair kits. Inclusive model institutions should be established to promote inclusive education. Repair kits and laboratories should be available to service inclusion units. Equipment and assistive devices for use by children with visual impairments should be stored in abundance and provided whenever they are needed.
\end{abstract}

Keywords: Inclusion, Visual Impairments, Blind, Low Vision.

\section{Introduction}

Inclusion of children with visual impairments was initiated in 1962 at Waddilove institution of the Methodist Church in Zimbabwe (Dakwa, 1983). The Royal Commonwealth Society of the Blind (R.C.S.B) established the Council for the Blind, In 1962, an organisation which has been instrumental in the establishment of the majority of resource units catering for the inclusion of children with visual impairments in Zimbabwe. Although the policy of including children with visual impairments was adopted in Zimbabwe, it has had its problems (Gatawa, 1998; Chikerema, 2010). The children are not properly included in terms of provision of services they require to fully participate in regular school activities (Chikerema, 2010; Dakwa, 2009).

Inclusion of children with visual impairments in Zimbabwe follows a "pull out" programme where the children participate in learning activities in the class with their peers but are withdrawn for 
specialist assistance in the resource room (Dakwa, 1983; Dakwa, 2008). These units in ordinary schools have been established by organisations and churches like the Jairos Jiri Association, Lutheran Church, Methodist Churches, Seventh Day Adventists, Presbyterians and Zion Christian Church (Peresuh and Barchan, 1998). It cannot be doubted that these churches and organisations have done a sterling job in promoting inclusive education for children with visual impairments in the country. The contribution of churches and other similar organisations in Zimbabwe has been part of the force that has fought and continues to champion the cause for the restoration of dignity and respect for persons with disabilities (Dakwa, 1985).

The Nziramasanga Commission (1999) indicated that some institutions and resource units had no proper equipment for use by children with disabilities. For the children with visual impairments, this included writing equipment like Perkins Braillers, writing frames, Braille books, mobility appliances for children who are blind as well as for the child with low vision. These appliances would equip the child with visual, impairment to be functional within an inclusive educational environment. The study intended to examine the inclusion of children with visual impairments within regular school settings.

\section{Conceptual Framework}

The Jomtien World Conference on Education for all (EFA) (1990), set the goal for inclusion and the accommodation of children with disabilities within regular school situations (UNESCO, 2002). The principle of inclusive education was adopted at the Salamanca World Conference on Special Needs Education (Salamanca Statement, 1994). The Salamanca Statement recommended that the child with special educational needs should be included in the school nearest to his/her home - the neighbourhood school. This policy of inclusiveness was further restated at the Dakar World Education Forum in 2000.

According to the Salamanca Statement (1994), the challenge confronting the inclusive school is that of developing a child-centred pedagogy capable of successfully educating all children, including those who have serious disadvantages and disabilities. Teacher education should, therefore, be transformed in order to support inclusion. At the same time, a curriculum should be created to accommodate a diversity of capabilities and learning styles (UNESCO, 2002; Ainscow, 1999) supports the concept and practice of inclusive classrooms and inclusive schools properly equipped to promote effective inclusion.

\section{Review of Related Literature}

Children with visual impairments can be defined as those having a visual impairment which, even with correction, adversely affects their learning (Kirk et al., 2006; Heward and Orlansky, 2009; Hallahan and Kauffman, 2006; Cassin and Solomon, 2006). Educationally, a child who is blind is one who learns through the medium of Braille (Hunt and Marshall, 2002). Children with visual impairments can either be blind or have low vision. The degree of visual loss would necessitate special educational adaptations to assist the children (Turnbull and Turnbull, 1995; Dakwa, 2009). 
Visual impairment should not limit the child's ability to compete with his peers. He should also be able to access facilities like education, health and social services. Full inclusion occurs when a child with visual impairments is accepted by his peers as a member of the regular class (Mastopieri and Scruggs, 2007). To this end, regular classrooms should be provided with adequate support to effectively enhance inclusion (Dakwa, 2009; Stainback and Stainback, 2004). The regular classroom should be considered as the least restrictive environment of the learning process.

According to Kirk, et al (2006), a significant amount of time should be spent guiding students in their preparation for learning and teaching them directly, employing a variety of techniques and technologies. Nziramasanga (1999) also echoes the need for the provision of adequate human, financial and material resources to facilitate effective inclusion of children. Dakwa (2009) discusses factors necessary for successful inclusion of the children with visual impairments :

- An accepting and flexible general education classroom teacher,

- Peer acceptance and interaction,

- Available support personnel, and

- Adequate supplies of equipment for both the child who is blind and one with low vision.

Inclusion is defined as a process of bringing all or nearly all exceptional children into the general classroom for their education, with special educational support (Kirk et al., 2006; Smith, 2001; Mastopieri and Scruggs, 2007). Inclusion involves a continuum of services which refers to the range of placement procedures, constituting the least restrictive environment where the child with exceptionalities learns best (Heward and Orlansky, 2009). According to the Salamanca Statement (1994), inclusive education entails that schools should accommodate all children, regardless of their physical, intellectual social, emotional, linguistic or any other condition. In other words, inclusion discourages any form of discrimination on persons with disabilities and children with exceptionalities.

Smith (2001) affirms that good, inclusive practices for students with disabilities require some adjustments to the learning environments and to teaching practices. To this end, the classroom furniture and learning material should be accessible to the child who is blind. Similarly, for the learner with low vision, there may be need to adjust seating positions, illumination and reading material to cater for different levels of vision, hence, the need for this study to evaluate the progress made in including children with visual impairments in Zimbabwean school settings.

Exciting technological advances open up a new world for people with severe visual disabilities. Advances in micro computer technology provide access to print information for the student with visual impairments. Electronic books allow the reader using a laptop to increase the size of print or to switch from voice to print easily (Heward and Orlansky, 2009; Hallahan and Kauffman, 2006; Kirk at el., 2006; Smith, 2001). People with visual impairments are gaining access to technology and assistive devices designed to minimize the negative effects of their disabilities. The following technological devices are available to learners and adults with visual impairments: Braille 
machines, talking watches, clocks, calculators as well as food scales (Kirk et al., 2006). Use of appropriate technological devices promotes effective inclusion.

Successful inclusion would entail the involvement of collaborative partnerships (Winzer, 1996; Ainscow, 1999). Although educators provide direct instruction to the learners with visual impairments, they are not alone in this exercise. They should employ the services of other professionals like psychologists, social workers, physiotherapists and speech therapists. These professionals will assist the teacher in planning best possible education for the learners. Although they may not be professionals in the technical sense of the term, parents and family members should be part of the team to effectively assist children with visual impairments. Collaborative effort will ensure that the child with visual impairments receives best practices from best people operating at best places.

The Education Act in Zimbabwe (1996) (revised), echoed the stand point that education is the right of every child, irrespective of differences on cultural and ethnic grounds. Similarly, the Disabled Persons Act of 1992 pronounced that persons with disabilities shall not be denied access to facilities on the grounds of their disabilities. It is with this view that the study examined the inclusion of children with visual impairments within the Zimbabwean context.

\section{Statement of the Problem}

Inclusion of children with visual impairments was initiated in Zimbabwe in 1962 by the Council of the Blind. Although successes have being recorded, daunting challenges have impinged on progress. Lack of adequately trained personnel and material resources have featured as problems to be resolved for both children who are blind and these with low vision.

\section{Purpose of the Study}

The study sought to examine the extent to which children with visual impairments were included in regular schools within the Zimbabwean situation.

\section{Research Questions}

The study was guided by the following research questions:

- Are children with visual impairments adequately catered for in an inclusive environment?

- Do regular class teachers possess relevant specialist qualifications and experience to handle children's problems?

- Are ordinary schools sufficiently equipped to promote inclusion?

- What challenges do schools meet as they attempt to include children with visual impairments in the regular classes?

- What support systems are available to the children? 


\section{Methodology}

\section{Participants (Sample) and Setting}

Teachers and pupils from resource units in the regular primary and secondary schools constituted the population. A survey design was employed for this study where interviews were used to determine views of the respondents who participated.

in the study. The sample included 30 teachers teaching children with visual impairments from 5 resource units in ordinary schools in two provinces (Masvingo and Midlands). These teachers were purposively selected. The teachers were selected on the basis of their involvement with the children. In addition, 40 children with visual impairments included in the same schools were randomly sampled. The children had to be randomly selected because the numbers of children with visual impairment included in the units in the ordinary schools exceeded 40.

\section{Instruments}

Interviews were conducted on both teachers and pupils to solicit the views of the respondents on the challenges faced by the participants regarding their participation in inclusive settings. Because of the sample sizes research assistants were employed in the interviews and collection of data. The researcher also recorded observations made during teaching practice sessions.

\section{Procedure}

Permission to conduct the study was obtained from the Ministry of Education Sport and Culture. Participants consented to participate in the study and their responses were kept in strict confidence as their names were not appended to their responses.

\section{Data Analysis}

Data collected from interviews and observations during teaching practice sessions were qualitatively analysed. Responses from the pupils and teachers were analysed to come up with themes related to the research questions. The analyses were based on frequency of similar responses from the participants. Data were explored by reading through all the interview responses as well as from the general observations made during teaching practice. Triangulation was achieved as responses from both the teacher and pupil samples as well as from general observations were cross examined. The objective of such triangulation was to improve on validity of the findings.

\section{Results}

\section{Are Ordinary Schools Sufficiently Equipped to Promote Inclusion?}

The teachers in the regular classes indicated that although inclusion was of benefit to the children, challenges were faced by the teachers and these issues necessitated rectification to enable the learners to benefit from inclusion more effectively.

Teachers indicated that there was little participation by children with visual impairments in sport. They confessed that they concentrated on sighted children for the sake of progress. Teachers also revealed that they could not cope with large numbers of children within the classroom situation. Attending to the child with visual impairments actually became an extra burden. 
Consequently, these children tended to be ignored as the teacher focused on the faster, sighted children.

Respondents cited lack of Brailled books. Teachers indicated that children with low vision lacked large print books, hence, they often strained their eyes as they struggled to read ordinary print. Some teachers in the regular classes revealed that assistance from specialist teachers came in too late and there was delayed induction in Braille for children who were blind.

\section{Are children with Visual Impairments Adequately Catered for in an Inclusive Environment? Children who were blind, indicated that they faced mobility and orientation problems. They experienced difficulties in moving around, understanding and locating their environments. Children also revealed that the classroom teachers ignored their needs when they continually used the lecture methods and ignored the presence of children with visual impairments. As revealed in the teachers' responses, the children also cited lack of Brailled books and other learning materials and how this hampered their learning progress.}

As was the case in the teachers' responses, children with low vision responded that they strained their eyes as they attempted to read the teacher's print on the board. They also cited the need for large print material as well as magnifying lenses to assist them with reading. The need to be taught writing skills featured in the responses of children with low vision whilst children who were blind indicated the need for learning devices such as 'talking' calculators, writing slates and styluses.

\section{What Challenges do Schools Meet as they Attempt to Include Children with Visual Impairments in the Regular Classes?}

These observations were based on visits to the resource units where children with visual impairments were included in the mainstream. Recordings from observations made during teaching practice supervision indicated similarities in problems impinging on successful inclusion of children with visual impairments within regular school settings. As indicated in both the teacher and pupil responses, observations during teaching practice supervision cited lack of Brailled books for children who were blind.

Although lack of assistive technology was observed in the inclusion centres visited, it was not only the lack of devices like Braillers and other writing materials, what emerged as a sore point was that if the equipment broke down, there were no repair kits available to repair the devices. Most assistive devices for children with visual impairments were imported either from the United Kingdom or United States of America. These repair kits were not easily available unless donor support was solicited.

Teaching practice records also noted the problem of large classes where teachers failed to effectively attend to individual needs of children with visual impairments. It was also evident that the teachers in the regular classes lacked specialist expertise to manage children with visual impairments. 


\section{Discussion}

The results and observations in this study have highlighted the need for resources and assistive technology to support inclusion, Kirk et al (2006), concur that exciting technological advances open up a new world for people with severe visual disabilities. In the process of inclusion, assistive technology gives children with visual impairments greater participation and independence. Technology can be applied by both the specialist teacher and the child to promote effective inclusion. Because disability imposes serious restrictions to an individual's ability to move about freely and confidently assistive technology has become a vital part to enable the child with visual impairment to move freely in order to access his/her environment and learning materials (Hallaham \& Kauffman, 2006).

It emerged from the study that children with low vision and those who were blind lacked expert assistance from the teachers in the regular classes. They, therefore, experienced isolation because the teachers were not adequately trained to meet their individual needs. It should be realised that whatever intervention measures taken to promote the inclusion of the child with visual impairment in the school situation are meant to provide quality life for him (Dakwa, 2009). The quality opportunities availed to him will lead to acceptance by members of the community of which he is an integral part. As teachers become more inclusive practitioners, they should focus on the provision of quality opportunities for the participation of all children in the class, in the school and community (UNESCO, 2002).

The problems of children with low vision were also highlighted in this study. These children faced difficulties to read print and information on the blackboard. The need for large print material to enhance reading is discussed, as well as seating arrangements to cater for distance and near vision. There is also need for the teacher to stand close to the child with low vision in order to over- verbalise instructions and information, Lighting conditions could be adjusted wherever possible to promote successful inclusion for children with low vision.

\section{Conclusion and Recommendations}

Results from both the teachers and pupils as well as observations recorded during teaching practice sessions revealed problems impacting on successful inclusion. The children could not fully benefit from inclusion owing to lack of adequate resources - specially qualified personnel as well as appropriate writing and reading materials. The study concluded that inclusion of children with visual impairments was not successful owing to the challenges encountered. These problems would need to be ironed out first to pave the way for effective inclusion of children with visual impairments in the regular schools. The study further concluded that the needs of children with low vision were not met as teachers were not adequately trained to assist these children.

The following recommendations emanate from the study.

- Inclusive schools should be established as model institutions to promote inclusion within their localities (Ainscow, 1999). 
- Regular classroom teachers should be in-serviced so that they are equipped to assist the children included in their classes.

- Assistive devices and repair kits should be available to both children who are blind and those with low vision.

- There is need to establish mini laboratories at school level and to employ peripatetic technicians who should move around institutions training specialist resource room teachers on the utilisation, repair and maintenance of assistive devices.

- A centralised assistive technology "bank" should be established at country level to service all the inclusion units.

- Existing special institutions should promote inclusion in the local regular schools.

\section{References}

Ainscow, M. (1999). Understanding the development of inclusive schools. London: Falmer Press. Chikerema, M. (2010). Challenges faced by children with visual impairment included in the regular schools in the Midlands Province. (Unpublished Bachelor's Dissertation) Great Zimbabwe University.

Cassin, B., and Solomon, S. A. B. (2006). Dictionary of eye terminology ( $6^{\text {th }}$ ed) Guinesville. FL:Triad.

Dakwa, F. E. (1985). The way forward. In Mavundukure,G. and Thembani, N. (2000). Comparative special needs education. Harare: Zimbabwe Open University.

Dakwa, F. E. (1983). An Investigation into the integration of visually handicapped pupils in four ordinary schools. Master's Dissertation : University of Wales-UK.

Disabled Persons Act. (1992): Harare: Government Printers.

Education Act. (1996). (Revised). Harare: Government Printers EFA. (Education for all). Global Monitoring Report. (2002). Is the world on track? UNESCO

Gatawa, B. S. M. (1998). The politics of the school curriculum. An Introduction. Harare : The College Press.

Hallahan, D. P., and Kauffman, J. M. (2006). Exceptional learners. Introduction to special education. Boston : Pearson.

Heward, W. L., and Orlansky, M. D. (2009) Exceptional learners. Introduction to special education. Boston: Merrill

Hunt, J. T., and Marshall, V.M. (2002). Aging, chronic illness and disability Hamilton, Ontario, Canada: Mark Nagler.

Inclusive Education in Southern Africa. Responding to diversity in education (2002). Harare: UNESCO.

Kirk, S. A., Gallagher, J. J., Anastasiow, N. J., and Coleman, M.R. (2006). Educating exceptional children. (11 ${ }^{\text {th }}$ ed ). Boston: Houghton Mifflin.

Lipsey, D. K., and Gartner, A. (1997). Inclusion and school reform. Transforming America's classrooms. Baltimore :Brookes

Mastopieri, M. A., and Scruggs. T. E. (2007). The inclusive classroom. Strategies for effective instruction ( $3^{\text {rd }}$ ed). New Jersey: Pearson.

Nziramasanga, C. T. (ed) (1999). Report on the presidential commission of enquiry into education and training .Harare: Government Printers 
Peresuh, M. N., \& Barcham, T., (1998). Special education provision in Zimbabwe. British Journal of Special Education 25(2), 75-80

Smith, D. D. (2001). Introduction to special education: Teaching in an age of opportunity. Boston: Allyn and Bacon.

Stainback, S., and Stainback, P. (2004). Inclusion : A guide for education. Baltmore: Paul Brooks.

Winzer, M. A. (1993). The history of special education: From isolation to integration. Washington DC: Gallaudet.

World Education Forum : Declaration on education for all (EFA). (2000) Assessment, thematic studies. Education for all and children who are excluded Dakar, Senegal (UNSECO).

World declaration on education for all (EFA). Jomtien Conference, Thailand (1990). UNESCO. 